\title{
Afgrundsblikket \\ - Det erotiske og repræsentationen hos Nietzsche og Sade
}

\section{Indledende bemærkninger}

Georges Bataille bestemmer erotikken som en bekræftelse af livet helt ind i døden (Bataille 2001: 15). Det menneskelige vilkår er præget af en erfaret diskontinuitet, og den erotiske stræben er ifølge Bataille en stræben efter kontinuitet og enhed. Ved diskontinuitet forstås, at vi, som individer, står på afstand af den anden og af verden, som vort begær eftertragter. Vi står på afstand af hinanden, og det, der skiller os, er en afgrund. Alene det forhold, at jeg lider min død og du din, at jeg forstår mig som radikalt forskellig fra dig og fra mine omgivelser, markerer denne afgrund imellem os. Som Bataille skriver:

Ethvert væsen er forskelligt fra alle andre. Dets fødsel, dets død og begivenhederne i dets liv kan vedkomme andre, men er kun direkte vedkommende for dette væsen selv. Det alene fødes. Det alene dør. Mellem et væsen og et andet er der en afgrund, der er en diskontinuitet. (Bataille 2001: 17)

At den erotiske stræben er karakteriseret ved en diskontinuerlig værens stræben efter kontinuitet, implicerer et paradoksalt forhold. Den erotiske stræben er knyttet til en repræsentation af det begærede, hvilket så at sige fikserer den erotiske stræbens retning. Den er underlagt anskuelsens distance, hvor individet fastholder repræsentationen som objekt for sit subjekt, hvilket fastholder individet i sin diskontinuerlige væren og fastholder den anden, den begarede, i repræsentationens lænker. Repræsentationen spiller således en dobbelt rolle. Den nærer den erotiske stræben ud over det diskontinuerlige vilkår, og den fastholder individet i sin diskontinuitet ved at fiksere distancen til det begærede. Som diskontinuerte væsener, der i vor erotiske stræben orienterer os ud over os selv, mod den anden, står vi således ved en afgrund, hvor repræsentationen, der nok nærer den erotiske ild, tillige fikserer distancen til det begærede og dermed føjer til afgrundsdybet.

I det følgende vil jeg behandle forholdet imellem repræsentation, transgression og afgrund hos Nietzsche og Markis de Sade. Sades liberti- 
nere dyrker repræsentationens systematik og søger dermed at bevare deres egen individualitet på ekstasens tinder. Når repræsentationens systematik er efterlevet og fuldbragt, må en ny overskridelse iværksættes. Nietzsche er sig repræsentationens reaktive ophav bevidst og søger derfor ikke overskridelsen i denne fiksering eller i fastholdelsen af individet, men derimod i den affirmative overskridelse af disse to forhold. Han søger den dionysiske rus, tilblivelsens uskyld, den indre erfarings oplevelse af kontinuitet og forløsning af alt. Dette markerer en klar forskel imellem Sades libertinerideal og Nietzsches overmennesketanke. Fælles for Sades libertinere og Nietzsches overmenneske er, at de søger at frigøre sig fra de sociale konventioner, moralske fordomme og religiøse påbud. Men hvor libertineren dyrker repræsentationens systematik og synes fanget i den evindelige gentagelse, forløses overmennesket ved den evige genkomst i den affirmative overskridelse af den reaktive repræsentation. Både Nietzsche og Sade har skuet i afgrunden og erkendt, at den gengælder vort blik: "Og hvis du ser længe nok ned i en afgrund, ser afgrunden også ind i dig" (Nietzsche 2005, JGB/IV/146).

\section{Viljen til magt og den reaktive repræsentation}

Den erotiske stræben er uløseligt knyttet til en repræsentation af det eftertragtede. Hos Bataille indtræffer det erotiske først, når seksualiteten omfavner døden i sin stræben. Denne død findes i det bevidstes fiksering af det kaotiske mangefold, i mere eller mindre stabile repræsentationer af det eftertragtede. Som Heraklit bemærker, er alt, hvad vi ser, dødt, fikseret og modsagt af det vordendes flux. Den erotiske stræben konstituerer derfor et udenfor sig selv, en distance til det eftertragtede, der fikseres $i$ repræsentation, som må erobres og fortæres. Denne distance er paradoksal, eftersom den etablerer et udenfor, der ydermere ikke kan forstås, medmindre vi anskuer med den erotiske optiks interesserede blik. Det er altså et udenfor, der er konstitueret af et passioneret indefra. Den idealiserede dyrkelse af denne repræsentation bestemmer Nietzsche som et reaktivt fænomen, som slavens dyrkelse af en mod- og ydre- verden, som slaven ophøjer til værdi, hvilket motiverer negationen af det, der modsiger denne repræsentations fikserede billede. Dette modbillede markerer distancen til den anden og føjer til afgrunden imellem os.

Nietzsche betragter selvet, den store fornuft (Nietzsche 1996: Z/I/5), som en syntese af stridende kræfter, drifter m.m., der står i et interpe- 
netrativt forhold til hinanden og konstituerer vores legeme som aktivt fortolkende tilstedeværen. Viljen til magt er syntesens plastiske princip, en patos, der er konkret instantieret i denne samfundsbygning af mange sjale (Nietzsche 2005: JGB/19). Den er en passioneret patos, som orienterer vor stræben, der gennem fortolkning, harmonisering og akkumulation af indtryk med mere, konstituerer et kontinuert selv. Modsat den platoniske Eros, der med distance i blikket søger bagom tilblivelsen, omfavner den affirmerende vilje tilblivelse $i$ en fortsat skabende stræben i sit eget billede. Viljen til magt søger at øge sin aktivitet, at føje stadigt flere nuancer til sit mønster, at bestøve og omfavne mere. Således implicerer den affirmerende vilje også et knusende nej til de reaktive repræsentationer, der bestandig modsiger dens fortsatte skabelse og stræben.

Dyrkelsen af de reaktive repræsentationer er, hvad Nietzsche kalder slaveopstanden i moralen. Slaven formår ikke at omsætte reaktionen til handling og aktivitet; Han er "nægtet den egentlige reaktion gennem handling" (Nietzsche 2008: GM/I/10). Da han ikke kan omsætte den modstand, han møder, til handling og således aktivt overskride den bestemmelse, den ydre aktivitet påtvinger ham, tyer han til en "imaginær hævn" (Nietzsche 2008: GM/I/10). Han lader sig reaktivt bestemme af sine omgivelser, men ophæver denne bestemmelse til værdi og hævder således negationen af sin egen aktivitet som efterstræbelsesværdig. Den aktive krafts affirmerende vilje dominerer den reaktive kraft og underordner således den reaktive kraft sit eget sigte. Den reaktive krafts imaginære hævn er at ophøje sit vilkår, det vil sige negationen af egen aktivitet, til værdi for således at gøre dette til syntesens sigte. Såfremt den har succes med dette, indlader syntesen sig på en nihiliserende sti. Negationen af den reaktive krafts sigte bliver syntesens samlede sigte. Den aktive kraft overvindes, ikke ved at den underkastes den reaktive krafts sigte, men derimod ved, at negationen af den reaktive krafts sigte bliver syntesens mål. Den negerer således tillige sin egen aktivitet $\mathrm{og}$ den reaktive krafts sigte. Den reaktive kraft formår således, gennem imaginær hævn, at adskille den aktive kraft fra dens implicitte sigte, hvorfor syntesens samlede sigte bliver den totale negation af begge kræfters skabende potentiale. Således udfolder syntesen en vilje til intet.

Begær og drift er som anført knyttet til repræsentationen. Vor optik former begæret, giver det retning og mål. Driftens reaktive billede fastlåses af ressentimentmennesket i repræsentationen - han behøver et udenfor, en fiktion eller et ideal. At forene multipliciteten af drifter, kræfter og 
deslige, er således inficeret med den optik, vi anlægger, og hvorvidt denne omfavner driftslivet, begærslivet og søger at forene disse i en overordnet selvkonception, eller hvorvidt denne optik, eksempelvis den religiøse, søger at fornægte visse aspekter af vores driftsliv og begærskrop, hvorfor disse aspekter står i bestandigt modforhold til en sådan selvkonception. Driftens reaktive billede kan anspore til en negation af driften selv og således anspore til kyskhed og selvfornægtelse. Når drifterne, hvoraf vor samfundsbygning, vort legeme, er konstitueret, presser sig på, vil det reaktive billede, nu ophøjet til ideal, anspore skamfølelse og yderligere nære ressentimentets kolde ild.

Modsat kan excessen også næres af det reaktive billede. Sades libertinere tjener som eksempel herpå. Kroppe fastlåses i bizarre positurer reguleret af en systematik og et reglement, der fikserer passionens billede i en frossen repræsentation, som fordrer efterlevelse af perversionens systematik. Slavens imaginære hævn består i at hævde det reaktive billede som ideal og værdi og følgelig gøre negationen efterstræbelsesværdig, enten ved afholdenhed i forhold til kraftens aktive sigte, næret af den reaktive repræsentation, eller ved dyrkelsen af det reaktive billedes systematik. Dette gælder således både det kyske bud og den perverse exces. Fælles for dem begge er, at de anskuer driftens sigte udefra.

Nietzsches overmennesketanke står i skærende kontrast hertil. Overmennesket skal ikke forstås som en tilstand, et stadie eller en bestemmelse, men derimod som en bro ( $\mathrm{Z} / \mathrm{I} / 4)$ over mennesket. Det vil sige over bestemmelsen menneske og menneskets diskontinuerlige vilkår. Dette implicerer, at man orienterer den mangfoldighed af drifter, som selvet er konstitueret af, hen imod en affirmativ omfavnelse af sin skæbne, Amor Fati. Men at favne sin skæbne betyder ikke blot, at man opregner alle fortidens hændelser og uhyrligheder og siger ja til disse, som Zarathustras æsel, der besvarer alt med " $I-A$ ". Overmenneskets $j a$ implicerer et knusende nej til de reaktive repræsentationer af fortiden, der bestandigt trænger sig på, bestemmer os, hæmmer os og tynger os. Overmenneskets ja er et aktivt levende ja, der forløser fortidens reaktive modbilleder, falske idoler, indgroede fortrængninger og moralske fordomme, ved trodsigt at knuse de reaktive repræsentationer i en affirmativ skabelsesakt. Dette er nødvendigvis en selvdisciplineringsakt, da det fordrer, at man søger indsigt i, i hvilken udstrækning man er bestemt af ydre forhold og negerende idealer, og at man søger at orientere de drifter, man er konstitueret af, og i stadig højere grad bringe disse i overensstemmelse med sin aktivitets sigte. 
Det er endvidere en transgressiv akt, eftersom overmennesket overskrider den reaktive bestemmelse af mennesket, diagnosen menneske, og favner mennesket som tillige: "skabning og skaber [...] stof, brudstykke, overflod, ler, skidt, vrøvl, kaos; [samt] skaber, formgiver, hammer-hårdhed, tilskuerguddommelighed og syvende-dag" (JGB225). Det vil sige mennesket som noget, der skal overvindes (Z/I/4). Overmenneskets $j a$ er et forløsende ja, i dansen, latteren, i den erotiske selvforglemmelse, i overskridelsen af menneskets diskontinuerlige vilkår og i den indre erfaring af kontinuitet - i excessens muntre dans ud over afgrundens kant, hvor et billede ikke vedbliver at være billede: "Hvor er der uskyld? Hvor der er vilje til at avle: Og den, som vil skabe ud over sig selv, har den reneste vilje. Hvor er der skønhed? Hvor jeg med al min vilje må ville; hvor jeg vil elske og forgå, for at et billede ikke skal vedblive at være et billede. At elske og forgå: Det hører sammen fra al evighed. Vilje til kærlighed, det er: at være villige selv til døden" (Z/II/15). For overmennesket er den evige genkomst den store test. Kan du ville alt, som har været, ved den evige genkomst af det samme, lyder spørgsmålet; thi fortiden vender tilbage i hver øjeblik, som noget afsluttet og bestemmende for din fremtid. Skaberen vender altid tilbage til sig selv som skabning og må forløse denne bestemmelse påny i endnu en skabelsesakt, $i$ endnu en dans, en latter, en erotisk selvforglemmelse ${ }^{1}$. Ved at forløse fortiden i en affirmativ overskridelse af de reaktive repræsentationer, der tynger mennesket og forhindrer det $i$ at give sig hen, omfavnes fortidens og fremtidens nødvendige sammenvævethed. Det internaliserede og levede ja til den evige genkomst implicerer i denne forstand en overskridelse af det diskontinuerlige vilkår og en erfaring af enhed og kontinuitet.

\section{Libertineren og den reaktive repræsentation}

Hos Sade skal billedet ikke blot vedblive at være billede. Det skal perfektioneres og systematiseres. Sade dyrker den reaktive repræsentation par excellence. Perversionens systematik dyrkes og perfektioneres, og arbitrære, konventionelle og moralske inklinationer sorteres fra, så passionens systematik kan fremstå klarere, renere og ondere. Libertineren er uløseligt bundet i sin perversion til den fikserede idé, der må næres og dyrkes, systematiseres og, i Sades tilfælde, nedskrives. Det er på transgressionens yderste tinde, at libertineren kan forene sig med sin eksistens, og dermed er eskaleringen og gentagelsen nødvendig. Ved at libertineren bliver forenet med 
sit projekts fuldbyrdelse, forenes han med sin eksistens, og det er netop denne forening af intellekt og passion, der konstituerer libertinerens eksistens. Men dette er tillige libertinerens endeligt, eftersom transgressionens tinde implicerer ophøret og fuldbyrdelsen af perversionens systematik, hvorfor foreningen af intellekt og passion kulminerer og disintegrerer $i$ selv samme øjeblik og efterlader libertineren hjemløs og splittet, hvilket fordrer gentagelse og eskalation.

Libertineren anvender den apatiske metode til at underordne sig den perverse gestus, der fuldbyrder og intensiverer fantasien. Dermed bliver libertineren et med sin perversion, der bliver manifestationen og fuldbyrdelsen af libertinerens eksistens. Den apatiske metode går kort sagt ud på at dulme følelsernes og passionernes rasen og blot lade deres billede stå, for således at dyrke og perfektionere dette billedes systematik og bud: "Lad det være dit hoved og ikke dit temperament, der befaler dine fingre" (Sade 1968: 641)). Den erotiske stræben bliver med Deleuzes ord deseksualiseret, hvorefter tanken seksualiseres: "Sadismens essentielle operation er seksualiseringen af tanken" (Deleuze 1991: 127). Den perverse gestus må således korrespondere med en repræsentation af overskridelsen, med hvilken libertineren kan forene sig og dermed opnå transgressionen. Hertil tjener narrationen og perfektioneringen af perversionens systematik, der går forud for libertinerens eksekvering.

Repræsentationen af overskridelsen implicerer et billede af den anden. Den anden holdes fastlåst i bizarre positurer, reguleret af en systematik og et reglement, der fikserer passionens billede $i$ en frossen repræsentation, som fordrer efterlevelse af perversionens systematik. Libertinerens optik tillader kun bødler og ofre, de lastefulde og de dydige, mekanikere og mekanismer. Det vil sige, at libertinerens optik gør offeret til genstand i ordets bogstavelige betydning og til genstand i en symbolsk betydning. Skal transgressionen være mulig, må libertineren kunne overskride sit og offerets vilkår, hvilket vil sige, at libertineren må bekræfte offerets objektstatus gennem handling og via fortælling. Altså må libertineren negere den andens subjektivitet, hvilket fuldbyrdes ved fikseringen af den anden som offer $\mathrm{i}$ den uaffekterede apatiske fantasi, og konkret: ved voldhandlingen. Libertinerens filosofiske diskurs er blandt andet kendetegnet ved den apatiske og systematiske dyrkelse af ideen, men for at transgressionen er mulig, må ideen tillige indeholde en forestilling om den anden som dermed kan overskrides. Der er således tale om en aktiv objektivering af den anden. Ydermere udelukker perspektivet, at libertineren kan opnå bevidsthed om sin egen 
kødelighed gennem en reciprok genkendelse af sig selv som seksuelt objekt for den anden. Det er en systematisk overvejelse af instinkternes mål, der ikke kan opnås, såfremt libertineren blot lader sig styre af affektioner.

Den anden spiller derfor en vigtig, men paradoksal rolle for libertinerens nydelse. Da libertinerens optik udelukker gensidighed, må libertineres bevidsthed om den anden, samt om sin egen kødelighed, konstitueres på anden vis. Denne konstitueres ved offerets lidelser og skrig. Libertineren Verneuil (Sade 1968) tvinger sin kone til at bære en kontraption, der forstærker hendes skrig og klage. Herigennem bekræfter hun sin frihed og subjektivitet, der netop er nødvendig for libertinerens overskridelse. Libertineren kan derved overskride den andens vilkår og negere den andens subjektivitet ved påførelse af de lidelser, der maler passionens blodige motiv. Når libertineren således fuldbyrder sin perverse gestik, antager han offerets frihed og bevidsthed for netop at negere disse, hvilket afføder skrig og smerte, der da rehabiliterer og genetablerer offerets position som frihed og bevidsthed, der nu igen må negeres og slutteligt destrueres. Altså må ethvert skrig besvares med et piskesmæld, et knivstik, et brændemærke eller hvad der nu behager. Dette må fortsætte til den endelige kulmination le petit mort, orgasmen og projektets fuldbyrdelse, eller le grand mort, destruktionen af offeret. I begge tilfælde ophører lyst/objekt-distinktionen mellem libertiner og offer. Le petit mort udsletter begæret ved dets opfyldelse, og le grand mort udsletter begærets genstand. Begæret og transgressionen er dog blot for libertineren momentant forløst, hvorfor et nyt offer og en ny transgression er nødvendig. Ved den aktive undertrykkelse og objektivering af den anden antages og overskrides den anden. Gjorde offeret ikke oprør var transgressionen ikke mulig. Libertineren må således kunne genkende sin egen passivitet i offeret.. Dermed kan libertineren opnå syntesen mellem krop og sind uden at forlade sig på gensidighed og uden at fortabe sig til kroppens afgrund; libertinerens fuldbyrdelse er en intellektuel overbygning på passionen. Ved aktivt at reducere offeret til kød og ved at genkende sin egen passivitet i offeret, får libertineren en privilegeret indsigt i sig selv som kød. Libertinerens suverænitet bliver således ikke komprimeret af sociale kår, moralske inklinationer eller tilfældige passioner ved fuldbyrdelsen af perversionens systematik.

Denne fuldbyrdelse kan tillige afstedkommes, hvis libertineren lader sig selv opleve smerten, og det er derfor ikke sjældent, at man i de Sades værker oplever, at libertineren lader sig piske, sodomisere eller lignende. Eksempelvis lader både Saint Fond og Dolmance (Sade 2005) sig selv 
smage pisken, og Dolmance finder tillige en særlig glæde $\mathrm{i}$ at udøve aktiv sodomi og være genstand for passiv sodomi på en og samme tid. Men for libertineren er den selvpåførte smerte ikke en underkastelse. Den er derimod en duplikering af offerets smerte, der er nødvendig, for at libertineren kan stå hævet over det fornedrede offer. Han må duplikere offerets passivitet ved at udsætte sig selv for smerten, for at kunne negere offerets subjektivitet. Der er således tale om en aktiv fordobling på et konkret og symbolsk plan. Passiviteten er subjektets identifikation med objekt-rollen. Den indeholder dog muligheden for oprøret, der manifesteres ved skriget. At udsætte sig selv for smerten er således en måde at genkende sin egen passivitet $\mathrm{i}$ den anden. Da Dolmance pisker Eugine, der er i lære som libertiner, og hun beklager sig over smerten, beslutter Sainte-Ange sig for at "hævne" hende, hvorefter Sainte-Ange griber en pisk og passioneret pisker løs på Dolmance. Dolmance takker for denne gestus og hævder sin konsistens over for Eugine. I smerten skal nydelsen omsider indfinde sig. At tillade dette frivilligt er at overskride offerets tilstand og dermed negere offerets subjektivitet. Ved at smage smerten duplikerer libertineren sit offers rolle, hvormed han negligerer og negerer offerets subjektivitet og forener kødet med den perverse gestik. Dermed spiller ydmygelsen en dobbelt rolle i libertinerens univers: dels ydmygelsen af offeret, der er en overskridelse og negering af offerets subjektivitet, dels ydmygelsen, der er at finde i straffen. I og med at libertineren genkender sin egen passivitet $i$ offeret, genkender han tillige sin egen straf. Ved at duplikere den seksuelle handling kan libertineren opretholde den intellektuelle distance, der fikserer målet, alt imens handlingen udføres.

For libertineren er al handling negation, hvorfor den absolutte negation efterstræbes. Således drømmer libertinerne om at omgøre skabelsen og berøve kroppen det liv, den har efter døden som bevægelse af stof, der indgår i naturens kredsløb. Naturen nægter enhver entitet evighed; dens lov er udtrykt ved bevægelse, kaos og destruktion. Efter mordet undergår offerets krop en metamorfose og er således i konstant bevægelse. Den døde krop optages af jorden for således at give næring til nyt liv. I den forstand dør kroppens stof aldrig, hvilket lader en forbrydelse tilbage, der dog ikke er indenfor libertinerens rækkevidde: "At angribe solen, flå den ud af universet, skabe et omsluttende mørke eller bruge denne stjerne til at brænde verden" (Sade 1966: 140). Den endelige tilbagekaldelse af væren og følgelig libertinerens egen destruktion er konsekvensen af denne absolutte fornægtelse. Sades libertinere søger i yderste konsekvens den to- 
tale negation, men eftersom den er uden for rækkevidde må de lade sig nøje med at indånde dødens suk. De må bestandigt på rituel ${ }^{2}$ vis gentage negationen, og i gentagelsen findes ingen genkomst. Hermed illustrerer de Sade objektiveringens radikale konsekvens, hvilket ydermere er fantasiens begrænsning: "Hvad vi gør, er kun billedet af hvad vi ville ønske at gøre" (Beauvoir 1966: 32). Offeret kan aldrig antage andet end en symbolsk funktion i libertinerens univers, og destruktionen fordrer derfor endnu en destruktion. Perversionen er således udtrykt ved en ensom idealiseret version af akten; den rituelle efterlevelse af sin fantasis systematik; den andens endeligt og begrænsning; libertinerens ensomme slot beboet af insekter - ingen personer.

Libertineren făr kun indsigt $\mathrm{i}$ den andens passivitet ved selv at duplikere og således gennem den aktive fornedrelse at stå over offerrollen. Libertineren hæver sig ikke, men formår alene at stå over offeret i kraft af at fornedres. I den dobbelte negation forener libertineren sig med sin eksistens gennem sine passioners fuldbyrdelse. Men på afstand, gennem systematik, ritual og fortælling. Således forener passionens systematik sindet og kødet. Libertineren skuer afgrunden i den anden. Den åbner sit gab og skriger med offeret, hvorfor offeret må tøjles med repræsenationens lænker. Men libertineren forbliver ensom i sin exces. Hans indsigt er, at for verden er vi alle dode.

\section{Transgressionens tinder}

Både Sades libertinere og Nietzsches overmenneske søger ud over de sociale konventioner og moralske fordomme. Begge har de skuet $\mathrm{i}$ afgrunden og erfaret det modbillede, afgrunden bærer i sit blik, men deres reaktion herpå er væsensforskellig.

Sades libertiner søger transgressionen i den apatiske dyrkelse af den reaktive repræsentation, hvilket udmunder $\mathrm{i}$ den totale negation af såvel offeret som bødlen. På en gang stiller han diagnosen menneske og bekræfter denne diagnose i overskridelsen. Hos Sade består overskridelse i den totale negation, hvilket på paradoksal vis bekræfter og fastholder den reaktive repræsentation, diagnosen menneske, som Sades alt for menneskelige overmennesker fikserer og dyrker på afstand, fikseret i utallige og ulidelige positioner. Fikseret af billedet, der opløses ved fuldbyrdelsen, le petit mort eller le grand mort, og således aldrig forløses, må Sades libertinere søge gentagelsen, eskalationen. Disse motiver males af den erotiske stræben, men 
den apatiske metode søger at stilne den erotiske passion for at få billedet til at stå stærkere og klarere. Passionen deseksualiseres, hvorimod den rene tanke seksualiseres. Libertineren er således ikke i det blinde begærs vold. Han står på afstand og søger at forene sig med sin diskontinuerte eksistens ved den systematiske efterlevelse af den slukkede passions tilbageværende billede. Han kan favne enhver død, på nær sin egen indtrædelse i kontinuiteten, hvilket er hans diskontinuerlige væsens endeligt. Han orienterer det erotiske begærs ojne og lader blikket slukke begærets flamme, for således at lade sig fortære af den rene tankes kolde ild. Afgrunden giver sig til kende i offerets skrig, en invitation til at se bag om repræsentationen, hvorfor libertineren må besvare skriget ved på ny at fiksere offeret i repræsentationens lænker. Således må livet bestandigt fortæres af døden i gentagelsen.

Libertinerens overmennesketanke er væsensforskellig fra Nietzsches overmennesketanke, der ikke lader sig reducere til den reaktive bestemmelse menneske. Nietzsches overmenneske er en bro, over mennesket, ud over diagnosen "menneske". En dionysisk:

trang til enhed, en rækken ud over personlighed, hverdag, samfund, realitet, som glemslens afgrund; [...] en ekstatisk affirmation til livets total-karakter, som det der er det samme, lige-mægtigt, lige-salig, i alle forandringer; [...] den evige vilje til avl, til frugtbarhed, til evig genkomst: en følelse af enhed i nødvendigheden af skabelse og destruktion (Nietzsche (1999): KSA 13:14 [14]).

Nietzsches overmenneske affirmerer sin skæbne, hvilket implicerer et nej til den reaktive repræsentation, der bestemmer og begrænser mennesket. Den affirmerende vilje er fritaget telos, idé og ekstern bestemmelse, som en immanent fortolkende, favnende og harmoniserende stræben, der bestandigt vinder sig selv i genkomsten af egen aktivitet, hvorfor den bestandigt vinder sig selv i sit afkom. Men som anført implicerer den erotiske stræben en repræsentation af, hvad den eftertragter, hvorfor den bærer distancen og perversionens afgrund med sig. Dermed betegner Nietzsches overmennesketanke ikke et endemål, men en bestandig stræben udover den reaktive bestemmelse, der på én gang er garanteret af og modsagt af den erotiske passionerede stræben. Overmennesket favner afgrunden i sig, men lader sig ikke reducere og bestemme af afgrundsblikkets modbillede, thi den sjal, der har den storste stige, når også dybest ned (Z/III/12/19). Sade negerer den reaktive bestemmelse i destruktionen, men vinder intet, end ikke sig selv. Han dyrker afgrundsblikkets modbillede, perfektionerer og efterlever dets systematik. Nietzsches overmenneske overskrider den 
reaktive bestemmelse, $\mathrm{i}$ en affirmerende bevægelse udover diagnosen og bestemmelsen menneske, der implicerer en erfaring af kontinuitet og erotisk selvforglemmelse. At elske og forgå (Z/II/15), således bekræfter erotikken livet ind i døden ved genkomstens enhed af skabelse og destruktion.

\section{Noter}

1 Denne tilgang til overmennesketanken og den evige genkomst, bliver yderligere begrundet og behandlet i min bog Flux - en bevagelse mod en heraklitiansk nietzscheanisme (Grimm 2011).

2 Ritualet modstilles her den masochistiske kontrakt.

\section{Litteratur}

Bataille, Georges (1992 [1973]): Theory of Religion, New York, Zone books

Bataille, Georges (2001 [1957]): Erotikken, Valby, Borgens forlag

Beauvoir, Simone de (1966 [1955]): “Must We Burn Sade?" i Makis de Sade, The One Hundred \& twenty Days of Sodom, London, Arena Book, Arrow Books Limited

Deleuze, Gilles (1991 [1989]): Masochism, New York, Zone books

Grimm, Jon Auring (2011): Flux - en bevagelse mod en beraklitiansk nietzscheanisme, Århus, Forlaget Armé.

Nietzsche, Freidrich (2008 [1887]): Moralens oprindelse (GM), Frederiksberg, Det lille Forlag

Nietzsche, Freidrich (2005 [1886]): Hinsides godt og ondt (JGB), Frederiksberg, Det lille Forlag

Nietzsche, Freidrich (1996[1883-1885]): Således talte Zarathustra (Z), København, Lindhardt og Ringhof

Nietzsche, Freidrich (1999): Sämtliche Werke: kritische Studienausgabe Bd 1-15 (KSA), Berlin, Deutscher Taschenbuch Verlag

Sade, Markis de (1968 [1797-1801]): Julliette, New York: grove press

Sade, Markis de (1966 [1904]): The One Hundred \& twenty Days of Sodom, London, Arena Book, Arrow Books Limited

Sade, Markis de (2005 [1795]): "La Philosophie dans le boudoir" i The Complete Marquis de Sade, Los Angeles, Melrose Publishing Company 
